\title{
Microeconomics and Tawhid String Relation Concept (TSR)
}

Submitted 11/03/20, 1st revision 19/04/20, 2nd revision 28/05/20, accepted 30/07/20

\author{
Lucky Nugroho ${ }^{1}$, Caturida Meiwanto Doktoralina ${ }^{2}$, \\ Fitri Indriawati ${ }^{3}$, Safira Safira ${ }^{4}$, Salimah Yahaya $^{5}$
}

\begin{abstract}
:
Purpose: This research focuses on microeconomics and Tawhid String Relation (TSR) in relation to Islamic law (Shariah) as it is used in everyday problem solving.

Design/Methodology/Approach: This study uses the content analysis method through a documentation study.

Findings: The results indicate that financial resources are not the only productive assets of individuals but what they are needed for the development of other factors within the Islamic concept.

Practical Implications: The study can contribute to promoting Islamic assets-e.g. microfinancing, Islamic Bank, Waqf, and Accounting zakat-which emphasize social justice. Regarding future research, the present findings need to be tested in the field.

Originality/Value: The study contributes to compiles prior research and contributes new interpretations to Indonesian researchers, especially concerning ethical, moral, social and religious factors that promote Islamic assets (e.g. the use of microfinance to emphasize social justice in accordance with Shariah).
\end{abstract}

Keywords: Islamic asset, microeconomic, microfinance, Tawhid String Relation.

JEL codes: D04, H7.

Paper type: Research article.

\section{Acknowledgements:}

The authors would like to thank the Ministry of Education and Culture, especially the Academic Assessor team of Dikti, Mercu Buana University, Jakarta Indonesia for their assistance and consulting for this publication.

\footnotetext{
${ }^{1}$ Universitas Mercu Buana, Postgraduate Program of Accounting. E-mail: lucky.nugroho@mercubuana.ac.id

${ }^{2}$ Corresponding author, Universitas Mercu Buana, Economics and Business Faculty, Department of Accountancy. E-mail: caturida_meiwanto_drm@mercubuana.ac.id, chess302@gmail.com

${ }^{3}$ Universitas Mercu Buana, Economics and Business Faculty, Department of Accountancy. E-mail: fitri_indriawati@mercubuana.ac.id

${ }^{4}$ Universitas Mercu Buana, Economics and Business Faculty, Department of Accountancy. E-mail: safira.almunawar@mercubuana.ac.id

${ }^{5}$ Universiti Teknologi Mara (UiTM) Cawangan Terengganu, Malaysia, Academy Contemporary Islamic Studies. E-mail: salimahyahya@uitm.edu.my
} 


\section{Introduction}

Islam is a comprehensive religion because all of the Muslims' activity already regulated in a great manner. The Qur'an is the main source of reference in solving problems, but if it is not stated clearly in the Qur'an, then the hadith or as-Sunnah can serve as a reference for a solution, and if the answer is not found in the hadith, then the interpretation of the rules so emerging (ijtihad) can be referenced. This is in accordance with the Prophet Hadith-i.e. 'I leave behind me two things, the Quran and my example, the Sunnah and if you follow these, you will never go astray' (Anas, 2011).

One of the solutions and the ways of life in the form of knowledge explained by Choudhury (2010) based on ethics (Sharia) and morals applied to the social life of the nation and state is that the ultimate objective is to achieve social well-being with the formula of TSR, as outlined in Figure 1.

Figure 1. Tawhid (Unity of God) Relationship Formulation

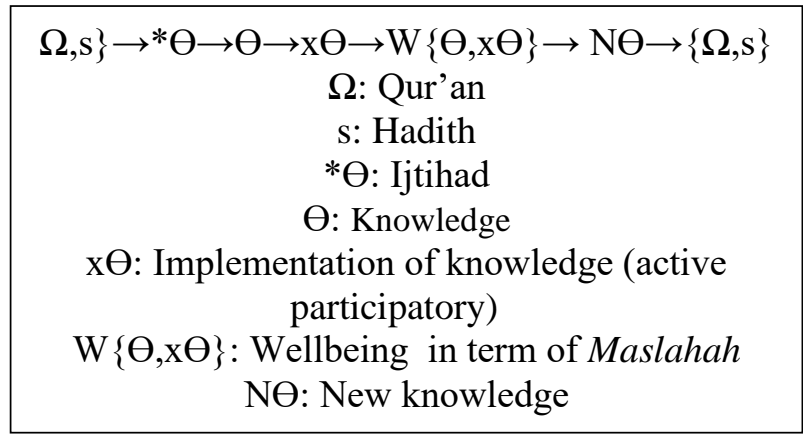

Source: Choudhury (2010).

The formula of TSR, as in Figure 1, explains that the main law of Islam is the Qur'an $(\Omega)$ because the Qur'an is derived from Allah SWT and passes on his word to the world. The law of Islam outlined by the Qur'an is related to the source of knowledge and a way of life for all human beings on earth (Hassan and Wan Khairuldin, 2020). Therefore, to enable use of the Qur'an, God sent Messengers to present it to mankind (ummah) in a way where the words and behaviours of the Messengers represented the real implementation of the Qur'an. The existence of the Prophet is very important as a tangible example of the application of the Qur'an. Furthermore, the words and deeds of the Prophet serve as hadith(s) by the companions' Messengers. When the prophet was still alive, the Hadith was not written down, but the companions memorized it. The companions did not feel the urgency of writing a hadith because it was still easy to get an explanation of everything from the Prophet. The definition of 'companion' is a person who met with the Prophet and died as a Muslim; in other words, a companion is someone who believes in the prophet and has touched and 
associated with him for a long time. However, problems began to emerge after the death of the prophet-i.e., who will be a role model for the ummah?

Therefore, the companions of the Prophet held an important role in the preparation of hadith, because hadith comprises the words, deeds, attitudes, and approval of the Prophet obtained from at least one companion who happened to attend or witness the statement of the prophet. The news was then subsequently submitted to another companion who happened to be present or not present. Further, the news was conveyed to his students called tabi'in (one generation under companions). The news was then submitted to the students of the next generation again such that the followers of the followers (Tabi 'al-Tabi'in) and so on up to the compilers of the hadith (mudawwin). In the next stage, in the current context in which the Prophet, companions, and Tabi 'al-Tabi'in gone, there was ijtihad $\left({ }^{*} \Theta\right)$. Ijtihad is work done by a religious person (Muslim scholar) to decide a case that is not discussed in the Qur'an and Hadith using science, common sense and mature judgment that is not contradictory with the Qur'an and hadith. Nevertheless, the Qur'an, hadith and Ijtihad should be considered the primary Muslim knowledge $(\Theta)$ for making decisions in every step of one's life. The Qur'an, hadith and Ijtihad must be active not only as knowledge but also as participation $(\mathrm{x} \Theta)$ from all the people and stakeholders to create well-being or maslahah $(\mathrm{W}\{\Theta, \mathrm{x} \Theta\})$.

The application of TSR must cover all aspects of human life (totality-kafah). Furthermore, TSR is a source of guidance for Muslims and also as a basis for the activities of Islamic organizations or institutions (Nugroho, Utami, Doktoralina, Soekapdjo, and Husnadi, 2017). At the same time, the implementation of the Shuratic process/role of Islamic law sources in human life can be used to solve any problem not only for the Muslim community but also to make a more just and humane world (Alwyni and Salleh, 2019). In addition to well-being, followers receive knowledge $(\mathrm{N} \Theta)$ on how to live better because maslahah guides the dynamic process needed to achieve a better life. The new knowledge must be based on the Qur'an and Hadith. Primarily well-being is in linking the TSR concept with its application to human life activities. The questions this paper will aim to address are as follows: (1) how is the concept of Islam related to knowledge, the objectives of Sharia (maqâshid sharia) and welfare? and (2) How can we apply TSR to institutional activities?

\section{Islam, Knowledge, Maqâshid Sharia, and Wellbeing}

In general, Islamic values are summarized into four basic principles: tawhid, balance, free will and responsibility 'my prayers, devotions, my life and my death is solely for the sake of Allah SWT, Lord of the universe'. This principle results in 'unity' that circles the orbit of monotheism, just as the planets of the solar system circle around the sun. Unity includes the unity of humanity, of the universe, of the world and of others. The unity of humanity, of the universe, of the world stated in the Qur'an Al Mulk verse 3, which in principle requires humans to not only live in a 
harmoniously balanced way and in harmony with themselves, but also leads them to create those three things in the community-i.e. always remember Allah SWT, be thankful for Allah SWT, the purpose of life is the afterlife, not the world and nature entirely. The purpose of Sharia (Islamic law) is to distribute wellbeing evenly across society (Ashour, 2006). Moreover, according to Kartikasari (2018), the goal of Sharia (maqâshid sharia) is to create maslahah as stated in the Qur'an Al-Anbiya verse 107 and Hadith Ath-Thabrani Number 3289-i.e., 'The best man is the most beneficial for others'.

Islam, as rahmatan Lil 'Alamin, is a religion that brings grace and prosperity for the whole universe, including animals, plants, the jinn and, of course, human beings (Ilyas, 2018; Nadjib, 2020). In general, Islam is not only a religion but also a way of life. Therefore, Islam conveys the message to humanity to create a humanitarian society where there is great affection for the poor, strong people help the weak, knowledgeable people share their knowledge with others, and people encourage each other to stay in a straight path. These traits are the core values that God has given to humans through the Qur'an. In other words, Islam is a religion that upholds the dignity of civilization and humanity by combining aspects of the material and the spiritual, and it should be implemented in public life as stated in Qur'an Al-Anbya verses 107.

Concerning environmental damage, this change was not due to the religion but due to ignorance and low levels of education, especially among those with low incomes. Islam gives great importance to the process of seeking knowledge, as stated by Prophet Muhammad: 'Seeking knowledge is obligatory for every Muslim (male and female)'. A tangible form of evidence of the glory of science in Islam is the first verse revealed by God to the Prophet Muhammad related to science stated in Qur'an (Surah Al-'Alaq, verses: 3-5): 'Recite, and your Lord is the most Generous-Who taught by the pen-Taught man that which he knew not'.

The Islamic perspective on science is very important because knowledge is viewed as a strategic and effective means of lifting human dignity from its downfall, as happened in the era of Jahiliyya. By educating oneself, one will gain knowledge and insight into the importance of knowledge management as a promising opportunity for one's future to be full of confidence and not easily manipulated (Loke, Fakhrorazi, Doktoralina, and Lim, 2020). In line with this, the Qur'an insists on the importance of intellectual responsibility in performing various activities because work that is done without the support of knowledge, expertise and skills is essentially considered invalid and not useful for the people and is destined to bring about destruction.

Maqâshid sharia refers to intent or purpose - what Sharia demands is a policy of wisdom to ensure the fulfilment of the happiness of living in the world and the afterlife. The happiness of living in the world and the afterlife can be interpreted to provide benefits and goodness and reject evil and destruction or maintain human 
benefit while avoiding the damage (mafsadat) and disadvantages of the various aspects of life in this world and the afterlife. Therefore, Choudhury and Alam (2013) states that according to the maqâshid sharia, which is realized by a balance of spiritual and physical needs so that towards maslahah (conditions, both material and non-material), which can improve the human position as the noblest creature; this state can arise from economic activities based on six components of maqâshid sharia (Arafah and Nugroho, 2016; Nugroho, Utami, and Doktoralina, 2019; Saad, 2020).

The six components are as follows: $a d$-din (safeguarding religion), nafs (preserving life), al-aql (safeguarding the mind), nasl wal 'ird (protecting descent), al-maal (supporting property) and hifz al-bi'ah (protecting the environment). Furthermore, Protecting the environment is gaining more attention in recent times due to the dynamics of environmental damage in the world at this time, which increasingly threatens human and non-human life (Rice, 2006). The argument for protecting the environment following sharia maqasid is based on maslahah, that is, the benefits for human life (Mufidah, 2016). Safeguarding becomes the first of maqasid sharia because the foundation for becoming a Muslim is faith in Allah SWT. Therefore, in the Qur'an and the Hadith, human faith in God is the foundation of Islamic economics. Then, the economic relationship with aspects of the aqeedah (creed) turn economic activity into a form of worship.

Meanwhile, it is necessary to preserve life because sustaining life also means preserving the right to live with dignity and preserve the soul to avoid persecution in the form of murder. Preservation of life is also sustained by eliminating food that can damage the body and health, including excessive consumption of food in general. Meanwhile, guarding the mind means viewing the human mind as a gift from God, which is very important and can distinguish between what is good and what is bad, what must be preserved and protected. For this reason, Sharia forbids alcohol and mind-altering substances, as they can kill the creativity of the human mind and cause moral damage. Thus, in Islamic economics, alcohol and the like are considered to have no value.

Maintaining descendants is aimed at utilizing the world as intended by Allah SWT to preserve the descendants of the next generation as good, strong and healthy. Because of this, Islam regulates marriages and forbids adultery and support the property. Specifically, all property belongs to Allah SWT, but Islam also recognizes individual personal rights. Islam provides regulations on buying, renting, borrowing or lending, promising, prohibiting fraud and practising usury (riba) to govern the system based on justice (Doktoralina and Nisha, 2020). The last of six component of sharia maqasid, which refers to protecting the environment, is based on the Qur'an (Ar-Rum, 60:41) where Allah SWT reveals the appearance of environmental damage caused by human activities, and humans having no choice but to accept the consequences of the environmental damage they have created, which threatens human existence, particularly for future generations. 


\section{Aim and Contribution of the Study}

The study uses the content analysis method through documentation study as a social research method (Bowen, 2009; Johnston, 2017). Using this method, the research aims to determine the capabilities and relevance of establishing the TSR concept framework of microeconomics base on sharia maqasid and applying general concepts of TSR to develop a persuasive model which can be tested again at an empirical level. This application of the TSR framework is followed by a discussion of the framework in relation to the theory that builds it.

\section{Discussion}

\subsection{TSR Implementation in Economics}

Islam is a perfect religion, and according to Ahmad (2019), Islam is a religion that is universal, humanist, dynamic, contextual and will last forever. Therefore, it is ordered to adherents to carry out the teachings of Islam as a whole, the totality ( $k a f f a h$ ) of which is stated in Q.S Al-Baqarah verse 208: 'O you who have believed, enter into Islam completely [and perfectly] and do not follow the footsteps of Satan. Indeed, he is to you a clear enemy'. Islam is the last celestial religion, which was revealed by Allah SWT to regulate human life, and which has characteristics that are very different from previous faiths that have been passed down by earlier prophets, such as religions passed on to Adam, Musa, AS, David, Isa AS and others. Islam, as the last religion, has governed matters that are philosophical and systemic and has arrived at practical rules, such as those pertaining to zakat, inheritance, marriage etc. Based on these practices, the Islamic religion, following common sense or rational thinking, can be viewed as a perfect or final religion (Reichmuth, 2016). Allah SWT has made full and comprehensive provisions to regulate human life so that these lives will be happy in and beyond the world.

Economics has a vital role in the life of humankind, particularly in the realm of how humans go about meeting their needs. Economics, in general, is defined as the study of social activities related to production, distribution and consumption of goods and services (Henderson, Dicken, Hess, Coe, and Yeung, 2002). Islam, as a perfect religion and a way of life for Muslims, certainly does not only regulate religion or spirituality but also regulates all aspects of human life (muamalah), including those related to economic activities. The activities of Islamic finance and business are not only limited to the material but also have a goal to meet human needs in an appropriate way (i.e. not excessively and greedily). Furthermore, Islam strongly denounces the greed for wealth and an overly materialistic orientation (Al-Zumai and Al-Wasmi, 2016; Bahari and Doktoralina, 2019; Doktoralina and Bahari, 2018).

However, Islamic Shariah does recognize the existence of individual rights to an object. Recognition of the right to individual ownership does not necessarily mean something is owned, and people should not act arbitrarily because they should also 
be considering others needs (Doktoralina, Nurhidayat, Fardinal, Irfan, and Isnaini, 2019). Islamic economics include a classifications of moral economics. This reflects how Islam is a comprehensive religion that regulates all aspects of human life through its teachings. The relevant values are reflected in the verses contained in the Qur'an, as well as the events described or explained in the Hadith, which are then applied in activities to meet the needs of human life (economic theory). There are three aspects of Islamic teachings: (i) Aqeedah-Faith, (ii) Sharia and (iii) morals. However, the three aspects cannot stand alone because they are closely interrelated. For example, in the element of Sharia (worship), a person must have a strong aqeedah foundation, as that foundation will impact sincerity in worshipping Allah SWT. Likewise, the relationship with moral aspects (e.g. how in worship, a Muslim must also be moral and ethical to Allah SWT), Islam recommends wearing clean and neat clothes, etc. All of these behaviours, if done comprehensively, will produce a noble goal, namely surrender to Allah SWT. Thus, the implementation of aqeedah, Sharia and morals is the key to the highest happiness both in the world and the afterlife.

\subsection{TSR Implementation in Institutional (Islamic Bank)}

Choudhury and Alam (2013) has discussed illustrations of the TSR relationship to variables in the institution such as Islamic bank. The study explained the concept of the institution or organization based on TSR and that the process of investment by shareholders in the institution should be based on knowledge and the implementation of knowledge as the embedded proxy to achieve social wellbeing. Furthermore, all elements which exist in organizations and institutions should be active in their interaction with each other in a dynamic environment. As an example of active interaction contained in Islamic banks is all employees and customers are brothers, so that the goal of Islamic banks is not solely to seek profit but to improve welfare. Therefore, all elements must help and complement each other so that Islamic banks can have excellent performance.

According to Choudhury and Alam (2013), there are three aspects in the organization that should be in interaction based on active and constructive participation to achieve maqhasid sharia; this interaction could create social wellbeing to the community. The elements cannot stand alone-it is the interactive knowledge that gives way to continuous improvement in the institutional process. The main objective of the Islamic organization is to realize maqâshid Islam alshari'ah. Maqâshid sharia can be fused into a single entity that leads to profitability, growth, stock ownership, output, income distribution and resolution of social issues. The entire variable (time, knowledge and space) contained within the organization to establish a complementary relationship and an entity (Choudhury, Rahman, and Hasan, 2018; Md Husin, Ismail, and Ab Rahman, 2016). The relationship between these variables is done with full consciousness to generate wealth for the common interest. This is the concept of equality, or in the terminology of Islam, almashlahah-wal-istihsan, which is well-being for the general-purpose (Choudhury 
and Hoque, 2006). So, in Islamic institutions such as the Islamic Bank, the Qur'an and Hadith are the two main pillars.

Every detail of the teachings of Islam should refer to the Qur'an and the Hadith. The Qur'an is the principal source of Islamic teachings as a guide for mankind (Hudanlinnasi); it serves as a guide for humans towards a prosperous life in the world and safely in the after world. In addition, the Hadith has the role of interpreting the Qur'an in practice or application of Islamic teachings in the factual world of human life. It would be difficult, without the 'intervention' of the Hadith, for the Qur'an to address real-life issues (especially legal issues) on a practical level. As a source of guidance for human life, of course, the teachings contained in the Qur'an and hadith should be implemented in public life. Islam as rahmatan Lil 'Alamin means that Islam is a religion that brings grace and prosperity for the whole universe, including animals, plants, the jinn and, of course, human beings, as stated in the Qur'an A1Anbya verse 107: 'And We have not sent you, [O Muhammad], except as a mercy to the worlds'.

The crisis in America, which resulted in a global economic crisis began with the engineering of subprime mortgage financial instruments, namely housing loans with low-interest rates in the 2001-2005 period, which impacted on the increasing demand for apartments and houses (boom in the housing market). The period of low-interest rates that occurred in the 2001-2005 period motivated the US public to behave consumptively but was sourced from loans in the form of loans to banks. Also, the low credit interest rate causes an increase in the expansion so that the derivative value of subprime mortgages exceeds the real price of the home used as collateral for credit. This securitization process has an impact on increasing credit risk, causing economic turmoil in lending not based on underlying assets. Furthermore, regarding Masyita (2015), Nugroho, Husnadi, Utami, and Hidayah (2017), in the macroeconomics view, the financial crisis was caused by the conventional financial intermediary. The process of the financial crisis in 2001-2005 can be described according to the outline in Figure 2:

Figure 2. Macro View of the Financial Crisis

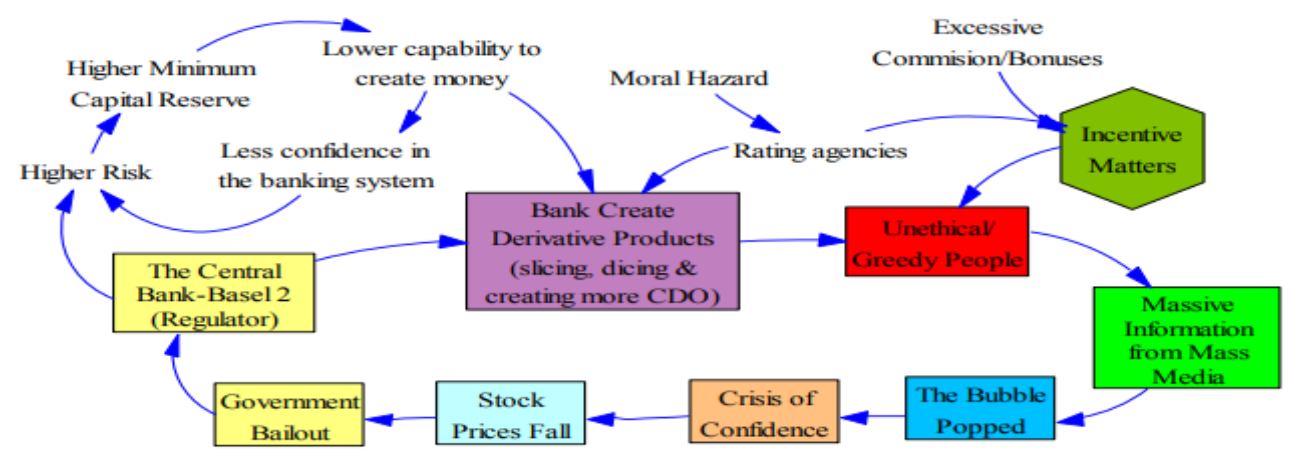

Source: Masyita (2015: p. 89). 
The Islamic Bank should create wellbeing for the community or ummah in the world - in other words, it could serve as the solution to the crisis. What is wellbeing? Wellbeing is the maslahah, and it means the Islamic bank should give a positive impact and benefits to all communities worldwide. Moreover, according to Nugroho, (2020), the Islamic bank can contribute to sustainable finance that combines four principles of Islam: Prophet, Profit, People, and Planet, as in Figure 3 below:

Figure 3. Islamic Bank as the Alternative Solution of Financial Intermediaries
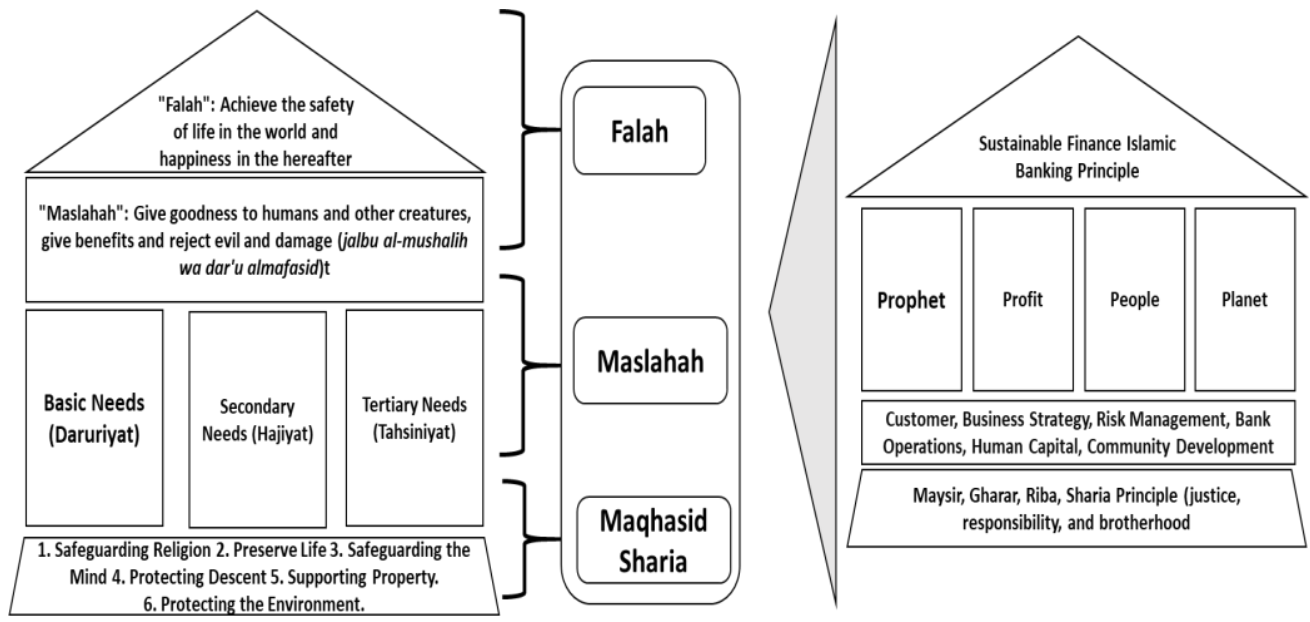

Source: Nugroho (2020).

Referring to Figure 3, the foundations of Islamic banks are Islamic maqhasid, which consists of six elements, among others, according to Fitrotulloh (2013) and Masruri and Rossidy (2007): (1) Safeguarding religion; (2) Keeping the soul; (3) Keeping intellect; (4) Safeguarding property; (5) Maintaining descent and (6) Protecting the environment.

The sharia maqhasid is implemented in everyday human life, namely in meeting basic needs, secondary needs and tertiary needs such that Sharia banking services have a role in supporting human life through business and financial transactions, and they need to follow the same vision and mission as other areas of Islam. The vision and mission must be based on sharia maqasid, which aims to achieve benefits and Falah. Besides, Islamic banking with its four pillars (prophet, profit, people and planet) aims to maintain a balance between business profits, moral and spiritual responsibilities and reducing social problems such as poverty, unemployment, social inequality etc. Furthermore, Islamic banks must also contribute to preserving the environment for the survival of the next generation. Therefore, the entire ecosystem of Islamic banks, both internal and external, becomes very important in realizing the sustainable finance of Islamic banking through application of Islamic principles: focusing on the needs of society and the ummah; fair business strategy and 
following industry needs; operational implementation based on Islamic values; implementation of risk management; appreciation for human resources that are objective and follow Islamic values; application of the principle of expediency for the welfare of society. In addition, Islamic banks, as financial intermediaries, have multiple bottom lines-i.e. not only financial performance but also social performance, environmental conservation and certainly, the spiritual aspects should be embedded (maqâshid sharia) in operations.

The link between the Islamic banking and microfinance is very close. The link is not based on the interest (riba) point of view but on the ideological and practical terms of microfinance. The microfinance origanility objective is to achieve the double bottom line (Hudon, Labie, and Reichert, 2018; Roy and Pati, 2019) In other words, microfinance institutions (MFIs) should not only be mindful of financial performance but also of social indicators. Econometric analysis is used to assess financial performance, and guidance is provided for extending the analysis of social performance indicators (Postelnicu and Hermes, 2018). Likewise, performance should be assessed externally through both financial ratios and social indicators (Armendariz and Labie, 2011; Armendáriz and Morduch, 2010; Balkenhol and Hudon, 2011). As a result, MFIs are frequently viewed as being designed to serve the unbanked poor, and they are seen by some as a magic wand against poverty that is supposed to solve it all (Nugroho, 2015); however, microfinance is neither a panacea nor a magic bullet, and it cannot be expected to work everywhere or for everyone.

There is a strong similarity between the purpose of microfinance and that of Islamic banks (Nugroho, 2015; Rozzani, Mohamed, and Yusuf, 2017). The shared purposes of the two include social performance and poverty alleviation (Begum, Alam, Mia, Bhuiyan, and Ghani, 2019). However, the practice of Islamic finance is based on the belief that money is not a productive asset in and of itself. Furthermore, in aiming to implement maqâshid sharia, the activities of Islamic banks, Islamic Microfinance can emphasize ethical, moral, social and religious factors to promote equality, justice and kindness (the ummah). Although this analysis of Islamic banking focuses on the economic aspects, the system can be fully understood only in the context of Islamic attitudes towards ethics, wealth distribution, social and economic justice and the role of the state. In these areas, the principles encourage risk sharing, individual rights and obligations, property rights and the sanctity of contracts (Dhumale and Sapcanin, 1998). According to Arafah and Nugroho (2016), Nugroho, (2017), Nugroho, Badawi, and Hidayah (2019), Islamic Banking should have microfinance services and products that are committed to addressing social issues such as environmental concerns, low-income communities, and concerns related to disability and gender. Islam is not just a religion. It encompasses the totality of its followers' views and ways of life. Islam is a religion that upholds the dignity of civilization and humanity and that combines aspects of the material and the spiritual world, and the world hereafter. 


\section{Conclusion}

This paper has argued that the practice of Islamic finance is based on the belief that money is not a productive asset in and of itself. Attention is also given to ethical, moral, social and religious factors and to the promotion of equality, justice and kindness according to the ummah. Ideally, Islamic Banking should have microfinance services and products that are designed to address social issues, such as environmental concerns, low income populations and concerns related to disability and gender.

Given the findings of this literature review, researchers in Indonesia, especially those in the area of Islamic microfinance, Islamic finance and accounting, should focus on the development of ethical, moral, social and religious parameters to promote equality and justice according to the concepts of ummah and mardhatillah (to receive blessings from God). The findings revealed here should also be tested in real empirical settings involving users and administrators of Islamic assets-e.g. microfinancing, Islamic Bank, Waqf, and Accounting of zakat.

\section{References:}

Ahmad, S. 2019. Qur'anic Guidelines for Personality Development and Collective Work. Islamiyyat, 41(1), 109-116.

Al-Zumai, F., Al-Wasmi, M. 2016. 2008 Financial Crisis and Islamic Finance: An Unrealized Opportunity. International Journal for the Semiotics of Law, 29(2), 455472. https://doi.org/10.1007/s11196-016-9469-6.

Alwyni, F.A., Salleh, M.S. 2019. Discourses on Development and the Muslim World. International Journal of Business and Social Science, 10(11), 135-147. https://doi.org/doi:10.30845/ijbss.v10n11p16.

Anas, A.A.M. 2011. Al-Muwatta. Beirut - Lebanon: Dar Al Kotob Al Ilmiyah. Retrieved from: https://books.google.co.id.

Arafah, W., Nugroho, L. 2016. Maqhashid sharia in clean water financing business model at Islamic bank. International Journal of Business and Management Invention, 5(2), 2232.

Armendariz, B., Labie, M. 2011. Introduction and Overview: An Inquiry into the Mismatch in Microfinance. In The Handbook of Microfinance, 3=13. London-Singapore, Scientific Work.

Armendáriz, B., Morduch, J. 2010. The economics of microfinance. MIT Press.

Ashour, M.T. 2006. Treatise on Maqasid al-Sharia (first). International Institute of Islamic Thought (IIIT).

Ath-Thabrani. 2020. Mu'jam Al-Kabir li Ath-Thabrani. In A. Wahid and N. Akbar (Eds.), Tafsir Ekonomi Kontemporer: Menggali Teori Ekonomi dari Ayat-Ayat Al-Qur'an (p. 349). Gema Insani.

Bahari, Z., Doktoralina, C.M. 2019. Economic Approaches of Zakat Management Institutions in Malaysia. In The First International Conference on Islamic Development Studies (ICIDS) (p. 10). Bandar Lampung, Indonesia, EAI. Retrieved from: http://dx.doi.org/10.4108/eai.10-9-2019.2289397.

Balkenhol, B., Hudon, M. 2011. Efficiency. In The Handbook of Microfinance, 123-138. 
London-Singapore, Scientific Work.

Begum, H., Alam, A.S.A.F., Mia, M.A., Bhuiyan, F., Ghani, A.B.A. 2019. Development of Islamic microfinance: a sustainable poverty reduction approach. Journal of Economic and Administrative Sciences, 35(3), 143-157. Retrieved from: https://doi.org/10.1108/JEAS-01-2018-0007.

Bowen, G.A. 2009. Document Analysis as a Qualitative Research Method. Qualitative Research Journal, 9(2), 27-40. https://doi.org/10.3316/QRJ0902027.

Choudhury, M.A. 2010. Islamic Perspective of Socioeconomic Development. Journal of Islamic Economics, Banking and Finance, 6(3), 1-18.

Choudhury, M.A., Alam, M.N. 2013. Corporate governance in Islamic perspective. International Journal of Islamic and Middle Eastern Finance and Management, 6(3), 180-199. Retrieved from: http://dx.doi.org/10.1108/IMEFM-10-2012-0101.

Choudhury, M.A., Hoque, M.Z. 2006. Corporate Governance in Islamic Perspective. International Journal of Islamic and Middle Eastern Finance and Management, 6(2), 116-128. https://doi.org/10.1108/14720700610655132.

Choudhury, M.A., Rahman, A.A.B., Hasan, A. 2018. Trade versus riba in the Qur'ān with a critique of the role of bank-saving. International Journal of Law and Management, 60(2), 701-716. https://doi.org/10.1108/IJLMA-03-2017-0021.

Dhumale, R., Sapcanin, A. 1998. An Application of Islamic Banking Principles to Microfinance. Study by the Regional Bureau for Arab States, United Nations Development Programme, in cooperation with the Middle East and North Africa Region.

Doktoralina, C.M., Bahari, Z. 2018. Zakat Accounting Information System in Private Higher Education. European Research Studies Journal, 21(3), 1-14. https://doi.org/DOI: 10.35808/ersj/1401.

Doktoralina, C.M., Nisha, F.M. 2020. Mudharabah Deposits Among Conventional Bank Interest Rates, Profit-Sharing Rates , Liquidity and Inflation Rates. International Journal of Financial Research, 11(1), 25-33. https://doi.org/10.5430/ijfr.v11n1p25.

Doktoralina, C.M., Nurhidayat, A., Fardinal, F., Irfan, I., Isnaini, I. 2019. The Role of Integrity and Hisbah in Acceleration Mechanism of Prevention and Corruption Eradication: An Islamic Accounting Perspective. In the First International Conference on Islamic Development Studies 2019, ICIDS 2019, 10 September 2, (p. 12). Bandar Lampung, Indonesia: EAI. https://doi.org/10.4108/eai.10-9-2019.2289349.

Fitrotulloh, M.R. 2013. Konstruk Filsafat dan Agama dalam Bingkai Peradaban Islam. ElQudwah-Qudwah, 4, 1-20.

Hassan, S.A., Wan Khairuldin, W.M.K.F., Embong, A.H., Yasin, M.F.M., Anas, N.I.W.N. 2019. Strategic Management in Fatwa-Making Process. Academy of Strategic Management Journal, 18(4). Retrieved from: https://www.abacademies.org/articles/strategic-management-in-fatwa-making-process8454.html.

Henderson, J., Dicken, P., Hess, M., Coe, N., Yeung, H.W. 2002. Global production networks and the analysis of economic development. Review of International Political Economy, 9(3), 436-464.

Hudon, M., Labie, M., Reichert, P. 2018. What is a Fair Level of Profit for Social Enterprise? Insights from Microfinance. Journal of Business Ethics, (July), 3-6. https://doi.org/10.1007/s10551-018-3986-z.

Ilyas, H.H. 2018. Fikih Akbar: Prinsip-Prinsip Teologis Islam Rahmatan Lil 'Alamin (Cetakan Pe). Indonesia, Pustaka Alvabet.

Johnston, M.P. 2017. Secondary data analysis: A method of which the time has come. 
Qualitative and Quantitative Methods in Libraries, 3(3), 619-626.

Kartikasari, P. 2018. Perbandingan Perlindungan Disabilitas di Indonesia dan Malaysia: Tinjauan Maqasid Asy-Syari'ah. Academica, 2(2), 303-312.

Loke, W., Fakhrorazi, A., Doktoralina, C., Lim, F. 2020. The zeitgeist of knowledge management in this millennium: Does KM elements still matter in nowadays firm performance? Management Science Letters, 10(13), 3127-3134. https://doi.org/10.5267/j.msl.2020.5.010.

Masruri, H.M.H., Rossidy, I. 2007. Filsafat Sains dalam Al-Qur'an: Melacak Kerangka Dasar Integrasi Ilmu dan Agama. El-Qudwah, 4, 1-24.

Masyita, D. 2015. Why Do People See a Financial System as a Whole Very Important? Journal of Islamic Monetary Economics and Finance, 1(1), 79-106. Retrieved from: https://doi.org/10.21098/jimf.v1i1.484.

Md Husin, M., Ismail, N., Ab Rahman, A. 2016. The roles of mass media, word of mouth and subjective norm in family takaful purchase intention. Journal of Islamic Marketing, 7(1), 59-73. https://doi.org/10.1108/JIMA-03-2015-0020.

Mufidah, R.H. 2016. Diskursus Pemikiran Fikih Lingkungan Ali Yafie dan Mujiono Abdillah. Supremasi Hukum, 5(1), 97-114.

Nadjib, E.A. 2020. Islam Itu Rahmatan Lil Alamin. Indonesia: Noura Books. Retrieved from: https://books.google.co.id/books?id=eEDWDwAAQBAJ.

Nugroho, L. 2015. Islamics Principle Versus Green Microfinance. EJIF - European Journal of Islamic Finance, 3, 1-9.

Nugroho, L. 2017. Challenges Sharia Microfinance Institutions: Evidence from Indonesia. European Journal of Islamic Finance, 1, 1-6. https://doi.org/10.13135/2421-2172/793.

Nugroho, L. 2020. Konsep Ekonomi dan Perbankan dalam Islam. In Pengantar Perbankan Syariah (1st ed., Vol. 1, pp. 1-26). Widina Bhakti Persada Bandung. https://doi.org/10.1017/CBO9781107415324.004.

Nugroho, L., Badawi, A., Hidayah, N. 2019. Discourses of sustainable finance implementation in Islamic bank (Cases studies in Bank Mandiri Syariah 2018). International Journal of Financial Research, 10(6), 108-117. https://doi.org/10.5430/ijfr.v10n6p108.

Nugroho, L., Husnadi, T.C., Utami, W., Hidayah, N. 2017. Maslahah and Strategy to Establish A Single State-Owned Islamic Bank in Indonesia. Tazkia Islamic Finance and Business Review, 10(1), 17-33.

Nugroho, L., Utami, W., Doktoralina, C.M. 2019. Ekosistem Bisnis Wisata Halal dalam Perspektif Maqasid Syariah (Halal Tourism Business Ecosystem in the Maqasid Syariah Perspective). Perisai: Islamic Banking and Finance Journal, 3(2), 84-92. https://doi.org/10.21070/perisai.v3i2.1964.

Nugroho, L., Utami, W., Doktoralina, C.M., Soekapdjo, S., Husnadi, T.C. 2017. Islamic banking capital challenges to increase business expansion (Indonesia cases). International Journal of Commerce and Finance, 3(2), 1.

Postelnicu, L., Hermes, N. 2018. Microfinance Performance and Social Capital: A CrossCountry Analysis. Journal of Business Ethics, 153(2), 427-445. https://doi.org/10.1007/s10551-016-3326-0.

Prophet Muhammad. 2019. Riyad as-Salihin: The Book of Virtues. (Imam An-Nawawi, Ed.). Scottsdale, Arizona. Independently published.

Reichmuth, S. 2016. The Arabic Concept of Dīn and Islamic Religious Sciences in the 18th Century: The Case of Murtadā al-Zabīdī (d. 1791). Oriens, 44(1-2), 94-115. https://doi.org/10.1163/18778372-04401005.

Rice, G. 2006. Pro-environmental behavior in Egypt: Is there a role for Islamic 
environmental ethics? Journal of Business Ethics, 65(4), 373-390. https://doi.org/10.1007/s10551-006-0010-9.

Roy, P., Pati, A.P. 2019. Double bottom line commitments of microfinance: evidence from Indian institutions. International Journal of Social Economics, 46(1), 116-131. https://doi.org/10.1108/IJSE-08-2016-0240.

Rozzani, N., Mohamed, I.S., Yusuf, S.N.S. 2017. Risk management process: Profiling of Islamic microfinance providers. Research in International Business and Finance, 41, 20-27.

Saad, H.M. 2020. The Basic Concept of Shariah (First Ed.). Malaysia, Pena Hijrah Resources. 